\title{
Substitution of fish meal with plant protein sources and energy budget for white shrimp Litopenaeus vannamei (Boone, 1931)
}

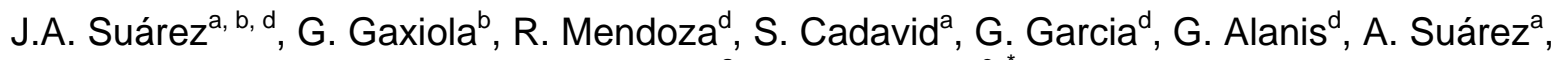 \\ J. Faillace ${ }^{a}$ and G. Cuzon ${ }^{c, ~}{ }^{*}$
}

\footnotetext{
a CENIACUA Corporación Centro Investigación de la Acuicultura de Colombia, Punta Canoa, Cartagena de Indias, Colombia

b UNAM Unidad Multidisciplinaría de Docencia e Investigación, Facultad de Ciencias, Sisal, Yucatán Lab Ecophysiologia, Sisal, Yucatan, Mexico

c Ifremer/COP, BP 7004 Taravao, Tahiti, French Polynesia, France

d Universidad Autónoma de Nuevo León, Facultad de Ciencias Biológicas, San Nicolás de los Garza, Nuevo Léon, Mexico
}

\begin{abstract}
*: Corresponding author: G. Cuzon, Tel.: +689 5460 35; fax: +689 5460 99, email address : Gerard.Cuzon@ifremer.fr
\end{abstract}

\begin{abstract}
:
Fish meal (FM) has long been considered an essential ingredient for the formulation of shrimp feeds. Until recently, 12\%FM was considered a minimum amount, below which weight gain would become reduced due to a reduction in feed intake. In order to test this perceived minimum value, an experiment was conducted on a long-term basis with 4 replicates. Four practical isonitrogenous and isoenergetic diets were formulated for Litopenaeus vannamei juveniles. Survival, weight gain, feed conversion ratio (FCR) and protein efficiency ratio were determined for 0, 6, 10 and 15\% FM diets and a reference diet. Shrimp survival ranged from 84 to $86.5 \%$. Shrimp fed a diet with $0 \%$ FM showed lower average weight and SGR compared to the other treatments $(P<0.05)$. FCR of shrimp fed the reference diet was significantly lower compared to the other treatments. Short-term energy budget did not differ in recovered energy (RE). Variations in RE according to FM level were expected, however, it remained low $\left(0.12 \mathrm{~kJ}_{\text {prawn }}{ }^{-1} \mathrm{day}^{-1}\right)$ and it was not possible to discriminate among dietary treatments. Data indicate that RE was similar as evidenced by an absence of difference in weight gain among 6,10 and 15\% FM diets and the reference diet $(0.98 \mathrm{~g} / \mathrm{wk})$. Growth results obtained over a long-term period and in clear water indicated the possibility for FM replacement with soybean plus canola meals.
\end{abstract}

Keywords: L. vannamei; Substitution fish meal; Plant proteins; Growth; Metabolism 


\section{Introduction}

For the last 20 years the production of fish meal (FM) and fish oil has remained fairly constant at around $6 \mathrm{Mt}$ for fish meal and 1Mt for fish oil. Aquaculture has taken an increasing share in the global fish meal production, with its estimated percentage increasing from 45 to 57 between 2002 and 2006. Marine fish meal is often utilized in aquafeeds because it offers a balanced source of indispensable amino acids, essential fatty acids, vitamins, minerals, and generally enhances palatability.

Protein ingredients selected to substitute for FM, either partially or completely, included terrestrial plant meals and animal by-products readily available on the world markets (Samocha et al., 2004). One factor considered in reducing shrimp production costs and increase producers' profitability is the use of feeds with low levels of FM and high levels of less expensive, high quality plant protein sources. Commercial shrimp formulations commonly include between $25-50 \%$ FM, representing the primary and most expensive protein ingredient (Amaya et al., 2007). Many studies have achieved considerable success in partially or totally replacing FM with plant protein sources in various shrimp species (Lim and Dominy., 1990; Piedad Pascual et al., 1990; Penaflorida et al., 1995; Eusebio and Coloso., 1998; Sudoryano et al., 1999; Alvarez et al., 2007).

Research has focused on the use of plant proteins to replace marine protein sources in formulated diets. Compared to other plant sources, soybean meal (SBM) is one of the most promising alternatives because of its availability, reasonable price, high digestibility (Lemos et al., 2000), and amino acid profile (Floreto et al., 2000). In terms of lipid composition, soybean meal contains $90 \%$ less n-3 fatty acids than fish meal and has anti-nutritional factors that may cause an inhibition of digestive enzyme activity. Several reports have evaluated canola meal as an ingredient for shrimp feed (Buchman et al., 1997; Lim et al., 1997; Cruz-Suarez et al., 2001). Canola or rapeseed ranks second behind soybeans in global protein production for oils and meals. Canola is the name given to selected varieties of rapeseed low in glucosinolate and erucid acid (Bell, 1993). Its amino acid profile is appropriate for aquaculture feeds and digestibility is similar to most other plant meals (Burel et al., 2000). Canola meal is a particularly rich source of sulphur-containing amino acids for fish feeds (Higgs et al., 1996). In commercial feeds, canola meal has often been combined with field peas to achieve a favorable amino acid profile (Davis et al., 2002).

However, the impact of these plant meals in actual practice has not been thoroughly evaluated; consequently, there is a need to improve our knowledge of feed utilization by shrimp (Gauquelin et al., 2007). One method that has been effectively used to predict waste outputs (Cho and Kaushik, 1990; Elliot and Hurley, 1999 for trout; Kaushik, 1998 for non-salmonids; Lupatsch et al., 1998 for sea-bream; and Zhou et al., 2005 for carp) and model growth (Cui and Xie, 1999) is bioenergetics. In contrast, for crustacean species (Comoglio et al., 2005), notably penaeid shrimp (Bureau et al., 2000), few studies have been published.

In this study, juvenile $L$. vannamei fed four substitution levels of soybean plus canola meal for FM was evaluated. Effects of dietary treatments on growth, survival, feed intake, feed conversion ratio, and protein efficiency ratio were determined. Energy partitioning within shrimp fed the different treatments was also studied in order to lay the foundation for further selective efforts to breed animals that are more efficient in utilizing feeds low in FM content. 


\section{Materials and methods}

\subsection{Animals}

Litopenaeus vannamei larvae were obtained from a nursery at CENIACUA from multipliers genetic material. Juveniles came from a culture in grow-out ponds at a stocking density of $80 \mathrm{shrimp} / \mathrm{m}^{2}$ and fed a regular pelleted commercial feed, Each tank was stocked with 100 animals with an average weight (av. wt) of $0.3 \pm 0.1 \mathrm{~g}$. Treatments were randomly assigned among 20 tanks, with each treatment having four replicates.

A sample of 12 shrimp (5.36 $\pm 0.32 \mathrm{~g}$ av. wt.) was randomly taken from each diet at the start of the experiment for the respirometry trial and energy budget calculations.

\subsection{Ingredients and diet preparation}

The feed ingredients used in this study were obtained from commercial suppliers through the NICOVITA ${ }^{\circledR}$ pilot feed mill plant. Soybean and canola meals were supplied through international distributors. Nutrient composition of soybean and canola meals is presented in Table 1. Four diets were formulated on an as-is basis (Table 2). Nutrient composition of the experimental and commercial reference diets is given in Table 3. The diets were prepared by mixing dry ingredients for $10 \mathrm{~min}$. Fluid ingredients were then added and the slurry was mixed for an additional $10 \mathrm{~min}$. The mixture was then steam-pelleted with a pellet mill at $90 \pm 2^{\circ} \mathrm{C}$ through a $2.5 \times 3 \mathrm{~mm}$ die. Pellets were ovendried at $73^{\circ} \mathrm{C}$ under constant air draft for $45 \mathrm{~min}$, bagged, and stored in a cool room $\left(24^{\circ} \mathrm{C}\right)$.

\subsection{Feed formulation strategy}

The four diets were isonitrogenous and isoenergetic. The two plant protein sources consisted of a mixture of soybean meal (46.9\% crude protein; $3.5 \%$ crude fat) and canola meal (38.9\% crude protein; $5.9 \%$ crude fat) providing 58, 69, 75 and $81 \%$ of the total protein in the diets by replacing fish meal protein. Dietary inclusion levels of fish meal were approximately 15, 10, 6 and $0 \%$, respectively (Table 2). Canola meal was used as a natural source of sulphur-containing amino acids, making a crystalline amino acids supplement unnecessary. Wheat gluten were used as an additional protein source and only added to the 0\% FM diet. Lipid levels were adjusted by adding a regular fish oil from a feed manufacturer in Lima, Peru. It was rich in highly unsaturated fatty acids (HUFA), such as decoeicosanoic acid (DHA) and arachidonic acid (AA). The four experimental diets were formulated based on the lysine (1.6\%) requirement (Fox, 1995) for L. vannamei and on P.monodon requirements in \% as fed for 0.9 methionine, (Millanema et al., 1996), 1.4 threonine (Millamena et al., 1997), 1.9 arginine (Millamena, 1998), 0.9 histinine, 1.1 isoleucine, and 1.7 leucine (Millamena et al., 1999) - The decision to formulate based on an AA requirement was made because overestimation and consequent loss of protein is possible when diets are formulated based on reference to muscle AA pattern or on previous recommendations (Akiyama et al., 1989).

\subsection{Analytical procedures}

Chemical analyses of ingredients, diets, and carcasses were contracted to professional analytical service providers and the Nicovita Chemistry Lab (Lima, Perú). Crude protein levels were calculated from the determination of total nitrogen by LECO auto-analyzer, based on Nx6.25. (AOCS, No. Aa 5-91). Crude fat content of the diets was determined gravimetrically following extraction of lipids according to the Soxhlet method (AOAC, No. 920.39). Amino acid concentrations were determined with an automatic AA 
analyzer (AOAC, 2000, No.988.15). Gross energy was determined by an adiabatic bomb calorimetry (ASTM D 5865-04). Standard procedures were used for moisture (AOAC, No. 934.01), crude fiber (AOAC, No. 962.09), and ash (AOAC, No. 942.05). Organic matter was calculated as dry matter minus ash. Water stability of the diets was determined at $1 \mathrm{~h}$ according to the method described in Aquacop (1978). The passage rate was evaluated as follows: each of the diets was tinted with a red colorant (®Radian Magruder Color, Magenta MS-M63018) to clearly differentiate feces as the colorant emerged from the digestive tract.

\subsection{Growth trials}

The feeding trial was carried out in clear water tanks without any productivity until the animals reached commercial size. During the 95 day trial, tanks were maintained in total darkness with $100 \%$ daily water exchange. Water temperature was $25.3-30^{\circ} \mathrm{C}$, salinity was $30 \pm 3 \mathrm{~g} \mathrm{I}^{-1}$, and dissolved oxygen was $5.9 \pm 0.64 \mathrm{mg} \mathrm{l}^{-1}$. Shrimp were distributed into 20 outdoor 500 I fiber tanks (2 sq. meter bottom) with 100 shrimp per tank. Tanks were covered with black plastic sheets. Treatments were randomly assigned among tanks, with each treatment having four replicates. Prior to starting the feeding trial, shrimp were acclimated to the experimental diets. Shrimp were fed five times daily at 04:00, 10:00, 15:00, 22:00 and 23:00 h. Dry feed intake was determined by feeding to satiation. Animals were fed daily with a control on feeding trays and observations of left-overs the next day in order to maintain the satiation. Feed intake was recorded daily to determine FCR At the conclusion of the trial, the following response variables were determined:

--weight gain = (final weight-initial weight/initial weight)

--SGR: specific growth rate $=100$ (In average final weight-In average initial weight)/number days.

--FCR = total dry feed intake $(\mathrm{g}) /$ wet weight gain $(\mathrm{g})$

--survival $\%=$ (final number of shrimp/initial number of shrimp) $\times 100$

--PER = weight gain in $\mathrm{g} /$ protein intake in $\mathrm{g}$

-DFI: dry feed intake per shrimp was estimated from the sum of average daily feed intake for each tank (DFI $=\sum_{i=1}^{95}\left[\left(\right.\right.$ intake on $i^{\text {th }}$ day) $/\left(\right.$ number of shrimp on $i^{\text {th }}$ day)

\subsection{Respirometry trial and energy budget}

Water temperature was constant at $28.5^{\circ} \mathrm{C}$, salinity was $35-36 \mathrm{~g} \mathrm{I}^{-1}$ and dissolved oxygen was $6.0 \pm 0.8 \mathrm{mg} \mathrm{l}^{-1}$. The information from the feeding trial was employed to build an energy budget following the nomenclature from NRC (1981). It was based on energy partitioning taking into account the following steps: intake energy (IE), digestible energy (DE), metabolizable energy (ME), urinary and branchial excretion (UE+ZE), and basal metabolism (HeE). Two control chambers without animals were used for each ten chambers. A metabolic chamber with continuous flow (Rosas et al., 1996) allowed oxygen consumption to be measured individually for 12 shrimp $(5.8 \pm 0.4 \mathrm{~g})$ selected from each diet. Dissolved oxygen at the entrance and exit of the respirometric chambers was measured using an oxygen microelectrode (Oxi 315i) and calculated according to:

$\mathrm{O}_{2} \mathrm{mg} \mathrm{mn}^{-1}=\left[\mathrm{O}_{2} \text { tank }\left(\mathrm{mg} \mathrm{L}^{-1}\right)-\mathrm{O}_{2} \text { control }\left(\mathrm{mg} \mathrm{L}^{-1}\right)\right]^{\star \text { flow rate }}\left(\mathrm{L} \mathrm{mn}^{-1}\right)$

Oxygen consumption transformed with the oxycalorific coefficient of $14.3 \mathrm{~kJ} \mathrm{~g}^{-1}$ (Lucas, 1996; Bureau et al., 2000) was used to calculate heat production (kJ). Urinary and branchial excretion (UE+ZE) was estimated at 6\% DE (Gauquelin et al., 2007). 


\subsection{Statistical methods}

All statistical analyses were made by using the Statistical Analysis Software Program of $\mathrm{SAS}^{\circledR}$ 2004. The responses calculated for each tank (mean body weight, biomass, growth rate, survival, feed intake, feed conversion, protein intake, PER) were subjected to an analysis of variance and then to the Duncan's multiple range test to first determine whether significant differences existed among the dietary treatments and then to identify where they occurred. The growth trial data were analyzed with a General Lineal Model where the effect of tank was nested among each diet. Results were considered statistically significant at $\mathrm{P}<0.05$.

\section{Results}

The nutrient composition of the soybean and canola meals is summarized in Table 1. The soybean meal had higher values for crude protein $(46.9 \%)$ and carbohydrate $(31.3 \%)$ than the canola meal, which had crude protein and carbohydrate values of 38.9 and $29.6 \%$, respectively. The fiber level in the canola meal was higher than that of the soybean meal by $60 \%$. In the same way, crude fat and ash content was higher in the canola meal. In regard to the amino acids analyzed, the methionine concentration in the canola meal was $0.79 \%$, whereas in the soybean meal it was $0.68 \%$. This represents a difference of $14 \%$ in favor of the canola meal. In the case of lysine, the difference was about $16 \%$ in favor of the soybean meal. For the other essential amino acids, the concentrations were higher in the soybean meal.

Composition of experimental diets is summarized in Table 3. All the experimental diets were isonitrogenous and isoenergetic. Nevertheless, the reference diet had the highest digestible energy level (DE), $17 \mathrm{~kJ} \mathrm{~g}^{-1}$ compared to $15 \mathrm{~kJ} \mathrm{~g}^{-1}$ for the $0,6,10$ and $15 \%$ FM inclusion diets. The reference diet had the lowest fiber level (1.8\%) compared to the other diets, which had levels ranging from 2.6 to $3.5 \%$. The percentage of carbohydrate was very similar between the experimental diets and the reference diet.

The reference diet had the lowest average time for passage rate $(56 \mathrm{mn})$, whereas the experiment diets ranged from 64-65mn ( $P>0.05)$.

Results of the feeding trial are summarized in Table 4. Survival of shrimp was high for all treatments ranging from 84 to $87 \%$ and was unrelated to diet. Shrimp fed the $0 \% \mathrm{FM}$ diet showed significantly lower average weight (12.2 \pm 2.5$)$ and SGR (3.8 \pm 0.2$)$ compared to other treatments. No significant difference in weight gain or SGR was observed among the $6,10,15 \% \mathrm{FM}$, and reference diet fed shrimp.

The variance in the harvest weights of the 0, 6, 10 and 15\% FM and reference diet fed shrimp was $6.3,6.8,6.1,5.6$, and 6.4 , respectively. These variances are very similar showing that the variability in the harvest weights among shrimp fed the different diets was very limited.

The average FCR was 1.91, which is acceptable because the experiment was conducted in clear water without phytoplankton and zooplankton being present. However, the FCR of shrimp fed the reference diet was significantly lower compared with that of the other treatments.

The average dry feed intake per shrimp per day (DFI) at the end of 95 days was $0.21 \mathrm{~g}$. No relevant difference in DFI values was observed among shrimp fed the $0,6,10$, and $15 \%$ FM diets. However, the DFI of shrimp fed the reference diet was significantly lower compared with the experimental treatments.

The average value for PER was 1.58. No significant difference was found among the 6 , 10, and 15\% FM diet fed animals. Shrimp fed the 0\% FM diet had a significantly lower PER $(1.41 \pm 0.05)$ compared to the other dietary treatments. The highest value for PER was obtained with the reference diet. The $6 \%$ FM diet corresponded to the maximum level of FM substitution by plant protein meals without affecting weight gain or survival. 
Energy budget, studied with $5.36 \pm 0.32 \mathrm{~g}$ av. wt animals fed the experimental diets, was measured on a weekly basis to obtain all the parameters derived from oxygen consumption (Table 5). The 0,6,10, and 15\% FM and reference diet produced a similar DE value of $0.9 \mathrm{~kJ}$ shrimp ${ }^{-1}$ day $^{-1}$. The estimated value in $\mathrm{kJ}_{\text {shrimp }}{ }^{-1}$ day $^{-1}$ from $\mathrm{UE}+\mathrm{ZE}, \mathrm{HiE}$, and HeE for all diets was also similar. The short-term energy budget did not show any apparent difference in recovered energy (RE).

\section{Discussion}

The soybean-canola meal combination is an appropriate substitute for FM in diets for $L$ vannamei at an $80 \%$ substitution level. This result agrees with that reported for Penaeus schmitti where $77 \%$ FM was replaced by soybean meal without affecting weight gain (Alvarez et al., 2007). The soybean and canola meal mixture was selected to replace FM due to its amino acid profile and digestibility (Suárez et al., 2008). Canola meal was selected because of its sulphur-amino acid content, which avoided the need for addition of crystalline amino acids.

The high survival during the feeding trial indicated the good health condition of the shrimp and confirmed the absence of any nutrient deficiency. Shrimp were harvested when they reached an average weight of $13 \mathrm{~g}$. Most nutritional studies are usually shorter in time, but in the present study harvesting occurred after 95 days to simulate the harvest time of an actual farming operation.

No significant differences were observed in weight gain or SGR among shrimp fed the 6,10 , or $15 \% \mathrm{FM}$ and reference diets. Growth results and survival confirmed that L.vannamei can be fed a mixture of plant meals ( $70 \%$ soybean- $30 \%$ canola meal) reducing FM level from 30 to $6 \mathrm{~g}$ per100 $\mathrm{g}$ dry weight. In the past, companies usually produced feeds with 30\% FM content for L.vannamei; 6\% FM would represent an $80 \%$ decrease in the FM content in L.vannamei feed formulations. Unexpectedly, shrimp maintained a consistent feed intake despite this dramatic reduction. Previously, acceptance was a previous concern which led to testing of several phagostimulants as well as growth factors and factors inducing vitellogenesis (Mendoza et al., 1997). However, the results obtained here with only $2 \%$ squid meal incorporation could have a significantly positive economical and environmental impact for the feed industry.

The relative complexity of replacing marine protein (Lim et al., 1998) has been mentioned previously (Fox et al., 1995; Lim et al., 2000) and there are many interactions at different levels. Total replacement of FM by plant proteins using $40 \%$ soybean meal (Amaya et al., 2007) produced a positive result; however the evaluations were made at a semi-commercial level in green water ponds and were probably influenced by a nutrient contribution from phytoplankton, zooplankton and benthos, masking the true contribution of nutrients from experimental diets. Primary productivity changes dramatically from zone to zone and is strongly affected by environmental conditions. For these reasons, it is probable that a $0 \% \mathrm{FM}$ diet would give satisfactory results when evaluated under commercial conditions together with the contribution of nutrients derived from primary production (Davis et al., 2002).. Differences in dry feed intake (DFI) among treatments were explained by inequalities in digestible energy (DE) among the reference (17kJ g-1) and practical diets (15kJ g-1). For example, Cousin (1995) reported a decrease in feed intake when the dietary energy increased for L.vannamei and P.stylirostris. In fish, differences in dietary energy can induce changes in feed intake (NRC, 1993). From a physiological view point, a longer passage rate could have facilitated an increase in digestibility by allowing digestive enzymes enough contact time but rates observed for the reference diet were slightly shorter than for the other diets. Therefore, it was only possible to get a marginal of improvement of average weight gain. Variations in oxygen consumption as a consequence of feed intake has two explanations: protein synthesis with no 
relationship between $\mathrm{HiE}$ and (UE+ZE) or oxidation of amino acids and production of ammonia. A distinction between excitation during a meal and HiE explained the variability, 9 to $20 \%$ of energy contained in a meal (Jobling, 1983). HiE could even represent a 50\% increase with respect to HeE (Beamish and Trippel, 1990; Hewitt and Irving, 1990). Routine metabolism, here called maintenance (HeE) is generally overestimated whether due to an insufficient period of acclimation prior to the measure of $\mathrm{HiE}$ or some inadequate environmental condition such as light, noise, vibrations, etc. Stated another way, basal metabolism rates in the literature are much too high and actually closer to the lower level of routine metabolism (Mc Mahon and Wilkens, 1983) and can be recalculated as 8 to $12 \%$ above the resting rate (Dall and Smith, 1986). The meaning of HiE (Baron Sevilla et al., 1994) has been given as a parameter that could only be explained as a product of the catabolism of protein. Nelson et al. (1985) reported a relationship between $\mathrm{HiE}$ and protein synthesis because the metabolic rate of $M$.rosenbergii increased from 7 to $39 \%$ when these prawns were fed different diets; moreover, when lipid or carbohydrate predominated, HiE dropped to 4 to $8 \%$. A feed rich in protein gave a $\mathrm{n} \mathrm{HiE}$ at 20 to $30 \% \mathrm{ME}$ and then increased with increasing protein content (Rosas et al., 1996). Does FM procure a lower HiE than plant protein sources? In a previous article (Suarez et al., 2008), it was made clear that HiE values for FM were lower than other protein sources. However, the trend was not repeated with a FM gradient. Koshio et al. (1993) observed that soybean protein produced elevated HiE compared to crab meal. So one would have expected to obtain lower HiE for higher levels of FM. FM is a complex compound compared to plant protein sources because it contains aside from intact protein other nitrogenous compounds such as nucleic acids, amines, etc. Therefore, the presence of high quality plant protein sources such as soybean or canola meals could compare favorably with FM. Hopefully there was no need to balance the diet with crystalline amino acids because amino acids could increase HiE (Carefoot, 1990). As shown previously, soybean meal was tested for ADC of amino acids that ranked high in L.vannamei, sometimes higher than some animal protein sources such as squid or shrimp meal (Akiyama, 1989).

Records of oxygen consumption and ammonia excretion on a daily basis are not reliable measures of short-term weight gain for technical reasons (Hewitt and Irving, 1990). The variations observed should be accompanied with observations of molting frequency and more precise measures of feed intake, extrapolated on a weekly basis. These two parameters of the energy budget, molt and feed intake, are particularly difficult to assess and that is why the level of data capture is considered less accurate than, for example, with rainbow trout (Bureau et al., 2000). By and large, it is possible to fit the weight gain response with energy partitioning over a short period. In this context, FM replacement got all its significance because the data were obtained over a long period with a reasonable survival. Protein accretion is good for animals fed low or high FM diets. In spite of a lack of control at the hepatopancreas level (HSI, lipid, glycogen), one can consider that further studies should focus on shrimp texture and taste (particularly at low FM content), immune response, and reproductive capacity. Moreover, shrimp produced from different families could be more or less prone to utilize low FM diets.

\section{Conclusion}

Our results for growth and survival confirm that L.vannamei can be fed plant meals ( $70 \%$ soybean-30\% canola), thereby reducing the quantity of fish meal from 30 to 6 $\mathrm{g} / 100 \mathrm{~g}$ dry weight (corresponding to a reduction of $80 \%$ ).

The differences in dry feed intake shrimp ${ }^{-1}$ day $^{-1}$ among the treatments are explained by the inequalities in DE. An increase of the DE level in a grower feed of about $17 \mathrm{~kJ} / \mathrm{g}$ could be envisaged to diminish intake. Two percent squid meal added to the diets was 
enough to ensure consumption. Analysis of anti-nutrients in plant meals would guarantee quality, it is also very important to carry out periodic digestibility studies on such ingredients.

\section{Acknowledgements}

Financial support for this study was provided by Corporación Centro Investigación de la Acuicultura de Colombia (CENIACUA) and ALICORP (Perú). Technical assistance was provided by the Unidad Multidisciplinaría de docencia e Investigación, UNAM. Sincere thanks to Brenda Montavan (Alicorp Perú) for her support and collaboration. The authors appreciate constructive inputs made by Dagoberto Sanchez (Alicorp Perú), Carlos Rosas, Javier Chiappa, Carlos Maldonado (UNAM, México), Marcela Salazar, Tomas Gitterle (CENIACUA, Colombia) and Roberto Mercado y Julia Star (Universidad Autónoma de Nuevo León, México).

\section{References}

Akiyama, D.M., Coelho, S., Lawrence, A.L., Roberson, E.H., 1989. Apparent digestibility of feedstuffs by the marine shrimp Penaeus vannamei Boone. Nippon Suisan Gakkaishi 55, 91-98

Alvarez, J.S., Hernandez-Llamas, A., Galindo J., Fraga, L., García, T., Villarreal, H., 2007. Substitution of fishmeal with soybean meal in practical diets for juvenile white shrimp Litopenaeus schmitti (Perez-Farfante \& Kensley 1997). Aquacult. Res. 38, 689695.

Amaya, E., Davis, A., Rouse, D., 2007. Replacement of fish meal in practical diets for the Pacific white shrimp (Litopenaeus vannamei) reared under pond conditions. Aquaculture 262, 393-401.

AOAC, 1990. Official Methods of Analysis of AOAC International, 12 ed.,Association of Official Analytical Chemists, Washington, DC, USA.

AOAC, 2000. Official Methods of Analysis of AOAC International, ??ed., Association of Official Analytical Chemists, Washington, DC, USA.

AOAC, 2004. Official Methods of Analysis of AOAC International., 17 ed., Association of Official Analytical Chemists, Washington, DC, USA.

Aquacop, 1978. Study on nutritional requirements and growth of Penaeus merguiensis in tanks by means of purified and artificial diets. Proc. World Maricult. Soc. 9, 225-234.

Baron Sevilla, B., Diaz Herrera, F., Bueckle Ramirez, L.F., 1994. Energy budget for the red swamp crawfish Procambarus clarkii (Crustacea, Cambaridae). Rivista italiana di acquacoltura. Verona 29, 103-107.

Beamish, F.W.H., Trippel, E.A., 1990. Heat increment: a static or dynamic dimension in bioenergetic models? Trans. Am. Fish. Soc. 119, 649-661.

Bell, J.M., 1993. Factors affecting the nutritional value of canola meal: a review. Can. J. Anim. Sci. 73, 679-697.

Buchman, J., Sarac, H.Z., Poppi, D., Cowan, R.T., 1997. Effects of enzyme addition to canola meal in prawn diets. Aquaculture 151, 29-35.

Bureau, D.P., Azevedo, P.A., Tapia-Salazar, M., Cuzon, G., 2000. Pattern and cost of growth and nutrient deposition in fish and shrimp: potential implications and applications. In: Cruz-Suárez, E., Ricque-Marie, D., Tapia-Salazar, M., CiveraCerecedo, R. (Eds). Avances en Nutrición Acuícola V. Memorias del V Simposio Internacional de Nutrición Acuícola, 19 al 22 de Noviembre, 2000, Mérida Yucatán, México 2000, pp. 111-140. 
Burel, C., Boujard, T., Tulli, F., Kaushik, S., 2000. Digestibility of extruded peas, extruded lupin and rapeseed meal in rainbow trout (Oncorhynchus mykiss) and turbot. Aquaculture 188, 285-298.

Carefoot, T.H., 1990. Specific dynamic action (SDA) in the supralittoral isopod, Ligia pallasii: Effect of ration and body size on SDA. Comp. Biochem. Physiol. 95A, 317-320. Cho, C.Y., Kaushik S.J., 1990. Nutritional energetics in fish: energy and protein utilization in rainbow trout (Salmo gairdneri). In: Bourne, G.H. (Ed.), Aspects of Food Production, Consumption and Energy Values. World Rev. Nutr. Diet. Karger, Basel, 61, 132-172.

Comoglio, L., Smolko, L., Amin, O., 2005. Effects of starvation on oxygen consumption, ammonia excretion and biochemical composition of the hepatopancreas on adult males of the false Southern king crab Paralomis granulosa (Crustacea, Decapoda) Comp. Biochem. Physiol. 140B, 411-416.

Cousin, M., 1995. Contribution à l'étude de l'utilisation des glucides et du rapport proteine/énergie chez P.vannamei et P.stylirostris. Ph.D. thèse INA/PG, Paris, 201pp.

Cruz-Suarez, L.E., Ricque-Marie, D., Tapia-Salazar, M., McCallum, I.M., Hickling, D., 2001. Assessment of differently processed feed pea (Pisum sativum) meals and canola meal (Brassica sp.) in diets for blue shrimp (Litopenaeus stylirostris). Aquaculture 196, 87-101.

Cui, Y., Xie, S., 1999. Modeling growth in fish. In: Theodorou, M.K., France, J. (Eds.), Feeding Systems and Feed Evaluation Models, CAB International, Wallingford, UK, pp. 413-434.

Dall, W., Smith, D.M., 1986. Oxygen consumption and ammonia-N excretion in fed and starved tiger prawns Penaeus esculentus Haswell. Aquaculture 55, 23-33.

Davis, D.A., Arnold, C.R., McCallum, I., 2002. Nutritional value of feed peas (Pisum sativum) in practical diet formulations for Litopenaeus vannamei. Aquacult. Nutr. 8, 8794.

Elliot, J.M., Hurley, M.A., 1999. A new energetic model for brown trout, Salmo trutta.

Freshwater Biol. 42, 235-246.

Eusebio, P., Coloso, R., 1998. Evaluation of leguminous seed meals and leaf meals as plant protein sources in diets for juvenile Penaeus indicus. Israeli J. AquacultureBamidgeh 50, 47-54.

Floreto, E.A., Bayer, R.C., Brown, P.B., 2000. The effects of soybean-based diets, with and without amino acid supplementation, on growth and biochemical composition of juvenile American lobster, Homarus americanus. Aquaculture 189, 211-235

Fox, J., Lawrence, A., Li-Chang, E., 1995. Dietary requirement for lysine by juvenile Penaeus vannamei using intact and free amino acid sources. Aquaculture 131, 279290.

Gauquelin, F., Cuzon, G., Gaxiola, G., Rosas, C., Bureau, D., Cochard, J., 2007. Effect of dietary protein level on growth and energy utilization by Litopenaeus stylirostris under laboratory conditions. Aquaculture 140, 361-372.

Hewitt, D.R., Irving, M.G., 1990. Oxygen consumption and ammonia excretion of the brown tiger prawn Penaeus esculentus fed diets of varying protein content. Comp. Biochem. Physiol. 96, 373-378.

Higgs, D.A., Dosanjh, B.S., Beames, R.M., Prendergast, A.F.,Mwachireya, S.A., Deacon, G., 1996. Nutritive value of rapeseed/canola protein products for salmonids. In Eastern Nutrition Conference, Halifax, Canada, May 15-17, pp. 187-196.

Jobling, M., 1983. Towards an explanation of specific dynamic action (SDA). J. Fish Biol. 23, 549-555.

Kaushik, S.J., 1998. Nutritional bioenergetics and estimation of waste production in non-salmonids. Aquat. Living Resour. 11, 211-217.

Koshio, S., Teshima, SI., Kanazawa, A., 1993. The effect of dietary protein content on growth, digestion efficiency and nitrogen excretion of juveniles Kuruma prawn, P.japonicus. Aquaculture 113, 101-114. 
Lemos, D., Esquerra, J.M., Garcia-Carreno, F.I., 2000. Protein digestion in penaeid shrimp:digestive proteinases, proteinase inhibitors and feed digestibility. Aquaculture 186, 89-105.

Lim, C., Dominy, W., 1990. Evaluation of soybean meal as a replacement for marine animal protein in diets for shrimp Penaeus vannamei. Aquaculture 87, 53-64.

Lim, C., Beames, R.M., Egles, J.G., Predergast, A.F., McLeese, J.M., Shearer, K.D., Higgs, D.A., 1997. Nutritive value of low and high fibre canola meals for shrimp (Penaeus vannamei). Aquacult. Nutr. 3, 269-279.

Lucas, A., 1996. Bioenergetics of aquatic animals., Taylor and Francis, (Ed.), London, Great Britain, , , 169pp.

Lupatsch, I., Kissil, G.W., Sklan, D. Pfeffer, E., 1998. Energy and protein requirements for maintenance and growth in gilthead sea-bream (Sparus aurata L.). Aquacult. Nutr. 4, 165-173.

McMahon, B.R., Wilkens, J.L., 1983. Ventilation, perfusion and oxygen uptake. In: The Biology of Crustacea ( Bliss, D.E. ed.). Internal Anatomy and Physiological Regulation, Vol. 5 ( Mantel, L.H. ed.), pp. 163-213. Academic Press,, pp. 337-341

Mendoza, R., Revol, A., Fauvel, C., Patrois, J., Guillaume, J-C., 1997. Influence of squid extracts on the triggering of secondary vitellogenesis in Penaeus vannamei. Aquacult. Nutr. 3, 55-63.

Millamena, O.M., Bautista, M.N., Kanazawa, A., 1996. Methionine requirement of juvenile tiger shrimp Penaeus monodon Fabricius. Aquaculture 143, 403-410.

Millamena, OM, Bautista, MN. Reyes, OS; Kanazawa, A.1997. Threonine requirement of juvenile marine shrimp Penaeus monodon. Aquaculture, 151(1-4) 9-14

Millamena, OM; Bautista-Teruel, MN; Reyes, OS, Kanazawa, A.1998 Requirements of juvenile marine shrimp, Penaeus monodon (Fabricius) for lysine and arginine Aquaculture. 164(1-4)95-104.

Millamena, OM, Teruel, MB, Kanazawa, A, Teshima, S. 1999. Quantitative dietary requirements of postlarval tiger shrimp, Penaeus monodon, for histidine, isoleucine, leucine, phenylalanine and tryptophan.Aquaculture. 179 (1-4)169-179.

Nelson, S.G., Simmons, M.A., Knight, A.W., 1985. Calorigenic effect of diet on the grass shrimp Crangon franciscorum (Crustacea:Crangonidae). Comp. Biochem. Physiol. 82A, 373-376.

NRC (National Research Council), 1981. Nutrient Requirements of Fish, National Academy Press, Washington, DC.

Penaflorida, V.D., 1995. Growth and survival of juvenile tiger shrimp fed diets where fish meal is partially replaced with papaya (Carica papaya) or camote (Ipomea batatas lam) leaf meal. Israeli J. Aquaculture-Bamidgeh 47, 25-33.

Piedad-Pascual, F., Cruz, E.M., Sumalangcay Jr., A., 1990. Supplemental feeding of Penaeus monodon juveniles with diets containing various levels of defatted soybean meal. Aquaculture 89, 183-191.

Rosas, C., Sanchez, A., Díaz, E., Soto, L.A., Gaxiola, G., Brito, R., 1996. Effect of dietary protein level on apparent heat increment and post-prandial nitrogen excretion of Penaeus setiferus, P.schmitti, $P$ duorarum and P.notialis postlarvae. J. World Aquacult. Soc. 27, 92-102.

Samocha, T.M., Davis, A.D., Soud, P.I., de Bault, K., 2004. Substitution of fish meal by co-extruded soybean poultry by-product meal in practical diets for the Pacific white shrimp, Litopenaeus vannamei. Aquaculture 231, 197-203.

SAS ${ }^{\circledR}$ 9.1.3 Copyright 2002-2005. SAS Institute Inc. Neuenheimer Landstr.28-30. Heidelberg, Germany.

Sudaryono, A., Tsvetnenko, E., Hutabarat, J., Evans, L., 1999. Lupin ingredients in shrimp Penaeus monodon diets: influence of lupin species and types of meals. Aquaculture 171, 121-133.

Warukamkul, P., Viyakarn, V., Nitithamyong, C., Piyatiratitivorakul, S., 2000. Effects of salinity and protein levels on energy budget of juvenile black tiger prawn, Penaeus 
monodon. IX International Symposium on Nutrition and Feeding of Fish, May 21-25, 2000, Miyazaki, Japan (abstract O56).

Zhou, A., Xie, S., Lei, W., Zhu, X., Yang, Y., 2005. A bioenergetic model to estimate feed requirement of gibel carp, Carassius auratus gibelio. Aquaculture 248, 287-297.

\section{Tables}

Table 1. Nutrientl composition (\% as fed) of soybean and canola meal

\begin{tabular}{lll}
\hline & soy & canola \\
Moisture & 8.26 & 9.12 \\
Crude protein & 46.9 & 38.9 \\
LYS & 2.71 & 2.26 \\
ARG & 3.57 & 2.11 \\
HIS & 1.26 & 1.09 \\
THR & 1.86 & 1.63 \\
LEU & 3.7 & 2.5 \\
ILE & 2.3 & 1.48 \\
VAL & 2.49 & 1.81 \\
MET & 0.68 & 0.79 \\
PHE & 2.38 & 1.53 \\
TRP & 0.66 & 0.48 \\
Crude fat & 3.45 & 5.92 \\
Crude fiber & 3.35 & 8.31 \\
Carbohydrate & 31.3 & 29.6 \\
GE (kJ/g DM) & 18.6 & 18.8 \\
Ash & 6.68 & 8.16 \\
\hline
\end{tabular}

${ }^{a}$ Carbohydrate (by difference)

use same size font as the rest of the paper

Table 2. Composition of experimental diets (values expressed on as fed basis, $\mathrm{g} / 100 \mathrm{~g}$ ).

\begin{tabular}{|c|c|c|c|c|}
\hline Fish meal a & 0 & 6 & 10 & 15 \\
\hline Squid meal & 2 & 2 & 2 & 2 \\
\hline $\begin{array}{l}\text { Soybean } \\
\text { meal }\end{array}$ & 49 & 45.5 & 42 & 35 \\
\hline Canola mealb & 21 & 19.5 & 18 & 15 \\
\hline $\begin{array}{l}\text { Wheat gluten } \\
\text { c }\end{array}$ & 4 & 0 & 0 & 0 \\
\hline Wheat flour & 21 & 15.9 & 17.9 & 23.9 \\
\hline yeast & 2 & 2 & 2 & 2 \\
\hline $\begin{array}{l}\text { Soybean } \\
\text { lecithin }\end{array}$ & 1 & 1 & 1 & 1 \\
\hline Fish oil & 5 & 4 & 3 & 2 \\
\hline Cholesterol & 0.4 & 0.4 & 0.4 & 0.4 \\
\hline $\begin{array}{l}\text { Vitamin \& } \\
\text { trace }\end{array}$ & 0.25 & 0.25 & 0.25 & 0.25 \\
\hline Stay-C 35\% & 0.10 & 0.10 & 0.10 & 0.10 \\
\hline Mineral mix & 3 & 3 & 3 & 3 \\
\hline Mold inhibitor & 0.15 & 0.15 & 0.15 & 0.15 \\
\hline
\end{tabular}


${ }^{\mathrm{d}}$ Vitamin and trace elements premix includes (IU/kg or $\mathrm{g} / \mathrm{kg}$ or $\mathrm{mg} / \mathrm{kg}$ of premix): retinol

, $10000 \mathrm{IU} / \mathrm{g}$; thiamin, $30 \mathrm{mg} / \mathrm{kg}$; riboflavin, $15 \mathrm{mg} / \mathrm{kg}$; DL Ca pantothenate, $50 \mathrm{mg} / \mathrm{kg}$; pyridoxin, $35 \mathrm{mg} / \mathrm{kg}$; cyanocobalamin, $40 \mathrm{mcg} / \mathrm{kg}$; ascorbic acid Stay-C, $150 \mathrm{mg} / \mathrm{kg}$; menadione, $3 \mathrm{mg} / \mathrm{kg}$; $D_{3}, 3500 \mathrm{IU} / \mathrm{g}$; a-tocopherol, $150 \mathrm{IU} / \mathrm{g}$; niacin, $100 \mathrm{mg} / \mathrm{kg}$; folic acid, 4 mg/kg; biotin, 1000 mcg/kg; Mn, 40 mg/kg; Zn, 40 mg/kg; Cu, 25 mg/kg; Fe, 100 $\mathrm{mg} / \mathrm{kg}$; Se, $0.3 \mathrm{mg} / \mathrm{kg} ; \mathrm{I}, 0.35 \mathrm{mg} / \mathrm{kg}$.

mineral mix $\mathrm{NaH}_{2} \mathrm{PO}_{4} ; \mathrm{KH}_{2} \mathrm{PO}_{4} ; \mathrm{MgCl}_{2}: 1: 1: 1$

change font size, first letter of each ingredient should be in caps, also use proper names of the vitamins usedOK

Table 3. Nutrient composition of the expermental diets (values expressed on as fed basis)

\begin{tabular}{|c|c|c|c|c|c|}
\hline FM & $0 \%$ & $6 \%$ & $10 \%$ & $15 \%$ & ref. * \\
\hline Moisture & 8.4 & 8.4 & 7.8 & 9.8 & 7.3 \\
\hline Crude protein & 39.3 & 38.6 & 40 & 38.6 & 36 \\
\hline crude fat & 8.8 & 8.8 & 8.1 & 7.2 & 7.0 \\
\hline crude fiber & 3.4 & 3.5 & 3.3 & 2.6 & 1.8 \\
\hline ash & 7.8 & 8.2 & 8.6 & 8.5 & 10.5 \\
\hline $\mathrm{DE}(\mathrm{kJ} / \mathrm{g} \mathrm{DM})^{\mathrm{a}}$ & 15 & 15 & 15 & 15 & 17 * \\
\hline carbohydrate $^{\mathrm{b}}$ & 32.1 & 36.4 & 32.1 & 33.3 & 37.2 \\
\hline LYS C & 1.9 & 2.1 & 2.2 & 2.2 & \\
\hline MET + CYS ${ }^{\mathrm{c}}$ & 1.0 & 1.1 & 1.1 & 1.1 & \\
\hline $\mathrm{ARG}^{\mathrm{c}}$ & 2.2 & 2.2 & 2.3 & 2.1 & \\
\hline $\begin{array}{l}\% \text { dry matter } \\
\text { loss }\end{array}$ & $9.34 \pm 0.5$ & $12.6 \pm 0.1$ & $13.3 \pm 0.10$ & $10.04 \pm 4.5$ & $13.2 \pm 1.1$ \\
\hline passage rates ${ }^{\mathrm{e}}$ & $64.3 \pm 0.5^{\mathrm{a}}$ & $65.3 \pm 0.1^{\mathrm{a}}$ & $64.1 \pm 0.10^{\mathrm{a}}$ & $63.8 \pm 4.5^{a}$ & $55.7 \pm 1.1^{b}$ \\
\hline
\end{tabular}

a Protein $=23 \mathrm{~kJ} / \mathrm{g}$, lipid $=35 \mathrm{~kJ} / \mathrm{g}$, carbohydrates $=15 \mathrm{~kJ} / \mathrm{g}$

* calculate obtained directly by apparent digestibility coefficients (method AIA)

${ }^{\mathrm{b}}$ Carbohydrate (by difference)

${ }^{\mathrm{C}}$ Calculated value

'Stability of the diets after $1 \mathrm{~h}$-immersion in seawater (Aquacop 1978).

e Passage rates in minutes. Values are means of eight replicates. Means within columnswith the same letter are not significantly different $(P<0.05)$

"commercial reference diet

Change font size in table, correct caps OK

Table 4. Growth and experiment diet utilization after 95 days (means of four replicates, means \pm std). 


\begin{tabular}{|c|c|c|c|c|c|c|c|c|}
\hline$\% F M$ & Survival $^{\mathrm{a}}$ & $\begin{array}{l}\text { Initial } \\
\text { mean wt } \\
\text { (a) }\end{array}$ & $\begin{array}{l}\text { Final } \\
\text { mean wt } \\
\text { (q) }\end{array}$ & $\mathrm{DFI}^{\mathrm{b}}$ & $\begin{array}{l}\text { Weight } \\
\text { gain }\end{array}$ & SGRc & FCRd & PERe \\
\hline 0 & $85,7 \pm 2,2^{a}$ & & $12,2 \pm 2,5$ & $0,22 \pm 0,06$ & $12.2 \pm 2,5^{b}$ & $3,8 \pm 0,2 b$ & $2,02 \pm 0,07$ & $\begin{array}{l}1,41 \pm 0,05 \\
\mathrm{c}\end{array}$ \\
\hline 6 & $82 \pm 1,6 a$ & & $13,1 \pm 2,6$ & $0,23 \pm 0,05$ & $12,8 \pm 2,5^{\mathrm{a}}$ & $3,9 \pm 0,2 a$ & $\underset{b}{1,97 \pm 0,10}$ & $\frac{1}{b}, 50 \pm 0,10$ \\
\hline 10 & $86 \pm 4,1 \mathrm{a}$ & $0.3 \pm 0.1$ & $13,2 \pm 2,4$ & $\begin{array}{l}0,22 \pm 0,01 \\
b\end{array}$ & $12,9 \pm 2,4 a$ & $3,9 \pm 0,2 a$ & $\underset{b}{1,84 \pm 0,07}$ & $\frac{1,50 \pm 0,03}{b}$ \\
\hline 15 & $86,5 \pm 1,2^{\mathrm{a}}$ & & $13,2 \pm 2,4$ & $\begin{array}{l}0,22 \pm 0,09 \\
b\end{array}$ & $12,9 \pm 2,4 a$ & $4,0 \pm 0,2 a$ & $\underset{b}{1,91 \pm 0,04}$ & $\frac{1,58 \pm 0,02}{b}$ \\
\hline ref. & $84,0 \pm 4,3^{\mathrm{a}}$ & & $12,8 \pm 2,5$ & $\begin{array}{l}0,19 \pm 0,04 \\
\mathrm{a}\end{array}$ & $12,6 \pm 2,5 a$ & $3,9 \pm 0,2 a$ & $\begin{array}{l}1,80 \pm 0,07 \\
a\end{array}$ & $\begin{array}{l}1,89 \pm 0,03 \\
a\end{array}$ \\
\hline
\end{tabular}

Values are means of four replicates \pm S.D. Means within columns with the same letter are not significantly different $(\mathrm{P}<0.05)$.

a Survival (\%)=Final number of shrimp/Initial number of shrimp $\times 100$.

${ }^{b}$ DFI: dry food intake per BIOMASS $=\sum 95 \mathrm{i}=1$ [(intake on ith day/(number of shrimp on ith day)

c SGR=100 (In average final weight - In average initial weight)/number of days.

${ }^{\mathrm{d}} \mathrm{FCR}=$ dry feed intake/wet weight gain.

e PER=weight gain in g/protein intake.

Correct font size also change, in numbers to $\mathrm{OK}$

Table 5. Effect of feed composition on a 24h energy budget ( $\mathrm{kJ}$ shrimp ${ }^{-1}$ day $\left.^{-1}\right)$ on the basis of two meal per day and with progressive FM incorporation in the diet (range of values). (RE approx.29\%).

\begin{tabular}{llllllll}
\hline $\begin{array}{l}\text { FM } \\
\text { level\% }\end{array}$ & DE & UE+ZE $^{(1)}$ & $\mathrm{HiE}$ & $\mathrm{HeE}$ & $\mathrm{RE}$ & $\begin{array}{l}\mathrm{HiE} \\
\mathrm{mg} \mathrm{O}^{2} \mathrm{~g}^{-1} \mathrm{~h}^{-}\end{array}$ & $\begin{array}{l}\mathrm{HeE} \\
\mathrm{mg} \mathrm{O}^{2} \mathrm{~g}^{-1} \mathrm{~h}^{-1}\end{array}$ \\
0 & 0.9 & 0.19 & 0.13 & 0.35 & 0.22 & 0.95 & 0.21 \\
6 & 0.9 & 0.18 & 0.12 & 0.33 & 0.26 & 0.88 & 0.20 \\
10 & 0.9 & 0.18 & 0.12 & 0.31 & 0.28 & 0.88 & 0.19 \\
15 & 0.9 & 0.18 & 0.11 & 0.33 & 0.27 & 0.81 & 0.20 \\
Ref. & 0.95 & 0.18 & 0.11 & 0.35 & 0.29 & 0.81 & 0.21 \\
\hline
\end{tabular}

Values are means of five replicates \pm sd. Means within columns with the same letter are not significantly different $(P<0.05)$.

DE: digestible energy measured previously (Suarez et al., 2008)

${ }^{(1)} \mathrm{UE}+\mathrm{ZE}$ : urinary and gills excretion about $6 \% \mathrm{DE}$

$\mathrm{HiE}$ : heat increment of feeding on the basis of one feeding per day

HeE: basal metabolism (maintenance) based on value measured at $t_{0}$

$R E$ : recovered energy

Ref. :commercial feed

Correct font size 